\title{
Gender in Multidimensional Peacekeeping Operations: Sexual Violence in Conflict
}

\section{Kayumova Alfiya Revolevna}

Kazan (Volga region) Federal University, 18 Kremlevskaya str., Kazan city, 420008, Republic of Tatarstan, Russian Federation

\author{
Doi:10.5901/mjss.2014.v5n24p483
}

\begin{abstract}
Sexual violence, abuse and mass rapes became a method of warfare long ago. Women and children are the most vulnerable category of the population becoming victims of crimes of all parties to the armed conflict. In most cases, their security and protection is the task of UN peacekeeping missions and regional organizations in peacekeeping. However, the reverse side of the Peacekeeping Operations "medal" is commitment of acts of violence by the peacekeepers. This situation undermines credibility of the UN and evokes a negative attitude of the civilians to UN personnel and members of the military contingent of operation. This article describes the problem of committment of sexual harassment and abuse by the peacekeepers, UN activities to resolve the situation, as well as issues regarding prevention, investigation and punishment for such crimes at the present stage.
\end{abstract}

Keywords: peacekeeping forces; sexual harassment; sexual abuse; sexual exploitation; The United Nations; safety and protection of women and children; criminal jurisdiction; responsibility of peacekeepers; gender training for peacekeepers.

"Conflict-related sexual violence is not specific to one country or continent: it is a global risk" - said Ms. Margot Wallstrom, Special Representative of the Secretary-General on Sexual Violence in Conflict, presenting in February 2012 the Secretary-General's annual report on conflict-related sexual violence to the Security Council [1].

Sexual violence against women and children is committed today not only by the warring parties. The cases of criminal acts committed by military men and other contingent of the mission against local civilian population in peacekeeping operations have increased in recent years.

Sexual crimes during UN multidimensional operations are not a new phenomenon: there is sufficient documentary and informal evidence to indicate that over the past decades there have been many instances of the personnel engagement in such acts, including liaising with adult prostitutes, demanding sexual favours in return for food or employment, sexual assault, rape and paedophilia [2]. Meanwhile, if the crimes against the UN personnel are often discussed, incidents of criminally punishable acts committed by the peacekeepers are actually not considered in the doctrine of the international law.

The problem has attracted an increased attention not so long ago in connection with cases of sexual exploitation and abuse by UN peacekeepers against the local population in the Democratic Republic of Congo. It turned out that the UN peacekeeping personnel was involved in crimes such as pedophilia, forced prostitution, rape, etc. This is not surprising, civilized Europeans do not go to hotspots to separate the warring parties any more, now these trips are made by soldiers of the Third World who have other standards of conduct and accustomed to lawlessness at home. As of today, the largest suppliers of "blue helmets" are Bangladesh, Pakistan, Nepal and India.

One of the first documents regarding commitment of sexual harassment and violence against the civilian population by peacekeepers was resolution 1325 (S/RES/1325 (2000) adopted by the Security Council at its 4213th meeting, on 31 October 2000.

According to the resolution, the following liabilities are assigned to the missions' contingent:

to respect fully international law applicable to the rights and protection of women and girls, especially as civilians, in particular the obligations applicable to them under the Geneva Conventions of 1949 and the Additional Protocols thereto of 1977, the Refugee Convention of 1951 and the Protocol thereto of 1967, the Convention on the Elimination of All Forms of Discrimination against Women of 1979 and the Optional Protocol thereto of 1999 and the United Nations Convention on the Rights of the Child of 1989 and the two Optional Protocols thereto of 25 May 2000, and to bear in mind the relevant provisions of the Rome Statute of the International Criminal Court; Calls on all parties to armed conflict to take special measures to protect women and girls from gender-based violence, particularly rape and other forms of sexual abuse, and all other forms of violence in situations of armed conflict. [3].

Despite the adoption of the document the situation became even more complicated in subsequent years. The number of allegations of sexual assault against UN peacekeepers and other personnel of the organization has increased 
more than twofold. This was reported by UN Secretary General Kofi Annan who called this situation "very serious."

British non-governmental charitable organization "Save the Children" published a report disclosing numerous cases of violence, including sexual abuse, against children by UN personnel in hotspots and disaster areas.

According to the report, more than half of the children said they were victims of sexual harassment, and each of them could recall ten or more cases with participation of the employees of the twenty-three peacekeeping and humanitarian organizations. Minimum age of the victims is 6 . Many children were pressured to have sex by force or in exchange for food and money. The UN personnel in the report is also accused of verbal sexual abuse, child trafficking and forced prostitution.

The report (to which the organization "Save the Children" gave the name "Not one to turn to") is based on confidential interviews conducted by its employees with 129 girls and 121 boys aged between 10 and 17 years in Haiti, Sudan and Cote d'Ivoire, the world's poorest countries where the UN personnel is currently working. The study showed that $18 \%$ and $23 \%$, respectively, were able to recall ten or more of incidents of sexual abuse by employees of peacekeeping missions. So, the boy aged 14 who worked in the UN camp in Cote d'Ivoire, said that the UN soldiers demanded to bring them girls to the barracks, insisting that they should be not older than 8 years. A 15-year-old respondent from Haiti spoke about employees of peacekeeping mission who suggested to her and her two girlfriends chocolate and about 3 dollars for oral sex. "I said no, but some of the girls did it and got the money", she added.

As for other UN agencies, the agency UNICEF which assists children registered two cases of sexual intercourse with minors. The World Food Program is currently investigating a scandal which was dubbed "sex in exchange for food". The UN High Commissioner for Refugees reported to Secretary General about 10 casesof this kind in his department. The United Nations Volunteers Programme (UNV) reported two sexual harassment allegations [4].

In pursuance of General Assembly resolution 57/306 of 15 April 2003 the United Nations Secretary-General on October 9, 2003 promulgated the Bulletin on Special measures for protection from sexual exploitation and sexual abuse addressed to all UN personnel [5].

The first section of the document states the following definitions:

The term "sexual exploitation" means any actual or attempted abuse of a position of vulnerability, differential power, or trust, for sexual purposes, including, but not limited to, profiting monetarily, socially or politically from the sexual exploitation of another.

The term "sexual abuse" means the actual or threatened physical intrusion of a sexual nature, whether by force or under unequal or coercive conditions.

In accordance with the Declaration on the Elimination of Violence against Women of the year 1993 (Article 1), the term "violence against women" means any act of gender-based violence that results in, or is likely to result in, physical, sexual or psychological harm or suffering to women, including threats of such acts, coercion or arbitrary deprivation of liberty, whether occurring in public or in private life [6].

In accordance with the Bulletin Special measures for protection from sexual exploitation all UN structural units must comply with certain standards prohibiting specific actions treated as sexual exploitation and sexual abuse.

As we know, military members of the national contingent provided by the Government are subject to the Government's exclusive jurisdiction. In view of recent developments and taking into account the recommendations of the Special Committee on mandatory provisions of the UN SG Bulletin for members of national contingents, the UN General Assembly in its resolution 60/289 of 8 September 2006 recommended the Secretary-General to provide as soon as possible the Member States with the revised draft model memorandum of understanding between the United Nations and Member States contributing resources to the United Nations peacekeeping operations, which is contained in Chapter 9 of the Guidelines for contingent-owned equipment, dated December 22, 2005. The revised draft model memorandum contains a lot of new provisions, and today many states contributing resources to UN missions signed it and the memorandum entered into force for those States; in some countries it is currently under consideration.

The key reform of the memorandum is the inclusion of the standards of peacekeeping contingent conduct into article 2 - "Documents constituting the memorandum of understanding". According to new Article 7 bis, all members of the Government's national contingent shall be bound by the United Nations standards of conduct thhat are set out in the Bulletin UN SG 2003 as well as the Code of Personal Conduct for "Blue Helmets" and "We Are United Nations Peacekeepers". The Government shall promulgate the standards in a form or manner that makes them binding under their laws upon all members of its national contingent. This can be achieved in various ways: by incorporating of the relevant rule into the national legislation, or in the form of command orders or internal regulations. The main responsibility for disciplinary action lies with the commander of national contingent.

In the event that UN has reason to suspect that any member of national contingent has committed an act of misconduct, it shall inform the Government and can initiate an administrative investigation with assistance from the Office 
of Internal Oversight Services, or a joint investigation with the troop-contributing country with the help of national experts of Legal Affairs. Similarly does the Government of the country that signed the memorandum: it shall immediately inform the United Nations on the suspected act of misconduct.

Signing the Memorandum of Understanding the Government of the troop-contributing country undertakes to exercise jurisdiction in respect of any crimes or offences that might be committed in violation of the UN standards of peacekeeping personnel conduct.

Following the adoption of the UN Security Council resolution authorizing the peacekeeping operation, a formal invitation is sent by the United Nations to the potential troop-contributing country in the form of a note verbale. Negotiations on the memorandum of understanding are then undertaken with the troop-contributing country, and a predeployment visit may be made by a representative of the Department of Peacekeeping Operations to provide a report to the troop-contributing country on the outcome of that visit. It is followed by negotiations, and it is often the case that the memorandum of understanding may not be signed for some months. The Special Committee concerns precisely such situations - when there is a gap in the legal regulation.

The UN Group of Legal Experts, created specially to handle the problem, presented its recommendations on December 18, 2006 [7]. The group started from the premise that each troop-contributing country must act in accordance with its own legal system to ensure compliance with the provisions of the Secretary General's Bulletin irrespective of whether it is done with the use of military or criminal justice. The Group report lists the ways to make provisions of the UNSG Bulletin legally binding upon the countries in the period prior to the conclusion of the memorandum. These are the following:

a) including in the note verbale one of the appropriate statements;

b) involvement of administrative resources of the UN force commander or the head of the UN mission, which may make orders binding upon military contingents;

c) designation of intolerance for sexual exploitation in the Security Council's resolution authorizing the operation;

d) implementation of relevant norms in national law.

Almost a quarter of complaints about the cases of sexual exploitation and abuse by peacekeeping operations contingent, which are registered by the UN Department for Peacekeeping Operations, is directed against the UN personnel. Currently, the prosecution of the UN staff (officials and experts on mission) is problematic because of their immunity under international law. The UN General Assembly also created a special Group on legal issues to develop recommendations ensuring that the UN staff and experts under any circumstances would not be exempted from criminal liability for criminal acts during the Peacekeeping Operations. The report submitted by the Group draws attention to a few basic questions.

The first question. Grounds for bringing to criminal responsibility. If the host State has functioning legal system, the crime should be investigated and prosecuted in accordance with the law of that State. In the opposite case, solution of the question may be affected by a number of factors:

a) adoption of the Code of Conduct of he said persons which will treat the committed acts as crimes;

b) determination of conduct as criminal in the state in which investigation is carried out;

c) differences in criminal laws of the Member States;

d) availability of immunity of this category of persons;

e) presence of the alleged offender in the state where investigation is carried out.

The second question. Ways of bringing to criminal responsibility. In general, it must be said that the Group gave priority to the execution of jurisdiction of the host State, which may be achieved by:

a) appropriate arrangements with the UN regarding a waiver of immunities of the persons who committed criminal acts;

b) each mission investment with the executive power;

c) hybrid tribunals creation (like the Special Court for Sierra Leone, the Extraordinary Chambers in the Courts of Cambodia).

In addition, the Group took into account that another state can execute criminal jurisdiction over the crimes basing on the active and passive personality principles. In this case, the Group recommends adopting international convention, the text of which has been specifically designed and annexed to the report.

The report also considered the issue of exercise of jurisdiction over the UN personnel by international judicial body - the International Criminal Court or a Tribunal especially established on the grounds of the Security Council Resolution (similar to tribunals for the former Yugoslavia or Rwanda). The Group made recommendations concerning procedures of possible investigations conducted in connection with the crimes committed by the UN personnel.

On March 7, 2008 the UN General Assembly adopted Comprehensive strategy on assistance and support to 
victims of sexual exploitation and abuse by the United Nations staff or related personnel, which contains recommendations to states on organization of such actions, including creation of special services and centers [8]. It is planned to create a United Nations focal point to coordinate and monitor implementation of the Strategy to ensure that the process of referring complainants, victims and children born as a result of sexual exploitation and abuse is simple, safe and respects the need for confidentiality, dignity and non-discrimination. Council:

On June 19, 2008 at the 5916th meeting the UN Security Council adopted Resolution 1820 (2008), in which the

a) Requests the Secretary-General, in consultation with the Security Council, the Special Committee on Peacekeeping Operations and its Working Group and relevant States, as appropriate, to develop and implement appropriate training programs for all peacekeeping and humanitarian personnel deployed by the United Nations in the context of missions as mandated by the Council to help them better prevent, recognize and respond to sexual violence and other forms of violence against civilians;

b) Requests the Secretary-General to continue and strengthen efforts to implement the policy of zero tolerance of sexual exploitation and abuse in United Nations peacekeeping operations; and urges troop and police contributing countries to take appropriate preventative action, including pre-deployment and in-theater awareness training, and other action to ensure full accountability in cases of such conduct involving their personnel;

c) Encourages troop and police contributing countries, in consultation with the Secretary-General, to consider steps they could take to heighten awareness and the responsiveness of their personnel participating in UN peacekeeping operations to protect civilians, including women and children, and prevent sexual violence against women and girls in conflict and post-conflict situations, including wherever possible the deployment of a higher percentage of women peacekeepers or police;

d) Requests the Secretary-General to develop effective guidelines and strategies to enhance the ability of relevant UN peacekeeping operations, consistent with their mandates, to protect civilians, including women and girls, from all forms of sexual violence and to systematically include in his written reports to the Council on conflict situations his observations concerning the protection of women and girls and recommendations in this regard;

e) Requests the Secretary-General and relevant United Nations agencies, inter alia, through consultation with women and women-led organizations as appropriate, to develop effective mechanisms for providing protection from violence, including in particular sexual violence, to women and girls in and around UN managed refugee and internally displaced persons camps, as well as in all disarmament, demobilization, and reintegration processes, and in justice and security sector reform efforts assisted by the United Nations.

On September 16, 2009 the UN published a UN SG Report "Women, Peace and Security". It contains information regarding the UN system activities carried out in the context of gender in the UN multidimensional operations.

Despite the encouraging statistics, acts of misconduct by peacekeeping personnel, according to the victims, still occur. In response, the UN and Member States ensure that all credible allegations are investigated and appropriate action is taken when allegations are substantiated.

At the last 68th session the United Nations General Assembly adopted the Secretary-General's report "Special measures for protection from sexual exploitation and sexual abuse" [9] which, in addition to the reports of sexual harassment and abuse on the part of the UN system organizations, contains measures taken by the organization to resolve the problem. These are the following: prevention of misconduct, enforcement of the UN standards of conduct and the remedial actions.. In particular, before deployment the UN provides training and education for contingent missions on conduct and discipline. For example, the United Nations rules forbid sexual relations with prostitutes and with any persons under 18, and strongly discourage relations with beneficiaries of assistance (those that are receiving assistance food, housing, aid, etc... as a result of a conflict, natural disaster or other humanitarian crisis, or in a development setting).

Great importance is given to preventing impunity for the crimes committed. The UN investigates its own staff. When allegations of misconduct involving military and police personnel are substantiated, the UN may repatriate the individuals concerned and ban them from future peacekeeping operations. The disciplinary sanctions and any other judicial actions remain the responsibility of the national jurisdiction of the individual involved.

Besides, it is assistance to victims of sexual exploitation and abuse committed by the UN personnel.

United Nations Secretary-General Ban Ki-moon said: "The United Nations and I personally are profoundly committed to a zero-tolerance policy against sexual exploitation or abuse by our own personnel. This means zero complacency. When we receive credible allegations, we ensure that they are looked into fully. It means zero impunity" [10]. 


\section{References}

Margot Wallstrom, Sexual violence as a weapon of war. Background note February 23, 2012. Date Views 20. 06. 2014. http://www.un. org/ru/preventgenocide/rwanda/pdf/bgsexualviolence.pdf

UN document A/60/980 d/d 16 August 2006. Date Views 05. 07. 2014. http://www.peacewomen.org/assets/file/Resources/ UN/un_ ensaccountunstaffpk_aug2006.pdf

UN document S/RES/1325 (2000) d/d 31 October 2000. Date Views 18. 06. 2014. http://www.ipu.org/splz-e/cuenca10/UN_1325.pdf

The number of sexual crimes in the United Nations has doubled. Date Views 12. 07. 2014. http://lenta.ru/news/2005/05/06/un/

UN document ST/SGB/2003/13 d/d 9 October 2003. Date Views 17. 06. 2014. https://un.org/en/oaj/files/unatjjudgments/2014-UNAT403.pdf

Declaration on the Elimination of Violence against Women. UN document A/RES/48/104 Date Views 22. 06. 2014. http://www.un.org/ documents/ga/res/48/a48r104.htm

Strengthening the rule of law through the United Nations Security Council. Date Views 07. 06. 2014. http://regnet.anu.edu.aul sites/default/files/Roisine_Burke_1.5_0.pdf UN document A/61/645 of 18 December 2006.

United Nations Comprehensive Strategy on Assistance and Support to Victims of Sexual Exploitation and Abuse by United Nations Staff and Related Personnel UN document A/RES/62/214 d/d 7 March 2008. Date Views 16. 07. 2014. http://www.un.org/en/ga/ search/view_doc.asp?symbol=A/RES/62/214\&Lang=E

Special measures for protection from sexual exploitation and sexual abuse. UN document A/68/756 d/d 14 February 2014. Date Views 10. 07. 2014. https://cdu.unlb.org/LinkClick.aspx?fileticket=YWVOYg-3aR8\%3D\&tabid=93\&mid=480

The UN expects that all peacekeeping personnel adhere to the highest standards of behaviour and conduct themselves in a professional and disciplined manner at all times. Date Views 20. 07. 2014. http://www.un.org/en/peacekeeping/issues/cdu.shtml 